non-Hodgkinリンパ腫の 1 例

\begin{tabular}{|c|c|c|}
\hline \multicolumn{3}{|c|}{ 東京医科歯科大学医学部第一内科 } \\
\hline 橋本 憲一○ & 赤川志のぶ & 高清水一善 \\
\hline 田村 厚久 & 寉田 哲朗 & 室田 直樹 \\
\hline 田，上雅彦 & 桃井 宏直 & \\
\hline & $\begin{array}{l}\text { 九段坂病院内科 } \\
\text { 光永 慶吉 }\end{array}$ & \\
\hline
\end{tabular}

\title{
A CASE OF NON.HODGKIN'S LYMPHOMA PRESENTING OPTIC NEUROPATHY INDUCED BY VINCRISTINE
}

Ken-ichi Hashimoto, MD, Shinobu Akagawa, MD, Ichizen Takashimizu, MD

Atsuhisa Tamura, MD, Tetsuroh Kubota, MD, Naoki Murota, MD

Masahiko TANOUE, MD and Hironao Momol, MD

The First Department of Internal Medicine, Tokyo Medical and

Dental University School of Medicine

Keikichi Mrtsunaga, MD

Department of Internal Medicine, Kudanzaka Hospital, Tokyo

\begin{abstract}
概要 Vincristineによる副作用として，末梢神経障害はしばしばみられる。しかし，中枢神経 である視神経障害は極めて希九で，本邦では末だ報告をみない，今回，我々は，non-Hodgkin リンパ腫の多薬併用療法中，vincristineによると思われる視神経障害を来した 1 例圭経験した ので報告する。症例は43才，男性。昭和56年 2 月ブドウ膜炎にて発症，次いで，発熱，表在り ンパ節腫大を来し，当初，サルコイドーシスとしてprednisoloneを投与され，一時下熱した。昭 和 57 年 7 月より, 再び $38 \sim 39^{\circ} \mathrm{C}$ の発熱, 表在リンバ節腫大が出現, 肝機能障害, 胸水, 腹水子 加わり重症化した。頝部リンパ節生挨の再娭討により lymphoepitheloid cellular lymphoma (Lennert's lymphoma) と䛦断, COPP療法にて下熱し, 諸症状の改善を办た。しかし，2クー

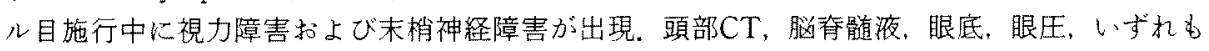
正常で, 視野の暗点抬大と後天性色覚異常あり, vincristineに上る球後視神経障害を疑い, 投与 を中止したところ，次第に眼の自他覚症状は改善した。これらの経過から，悪性リンパ腫によ るものとは考えられず, vincristineによる視神経障害と診断した。 vincristineは主に胆汁より排 泄されるとされ，本例に执いては，肝機能障害により本剂の神経毒性が増強されたものと思放 れる。
\end{abstract}

\section{緒言}

Vincristine (以下VCR) はVinca alkaloidsに属 する抗腫瘍剤で, 近年, 白血病や, 墨性リンパ腫, さらに固形癌の一部のものに対し，有効な薬物と

\section{〔昭和58年11月11日受稿]}

本論文の要旨は，第25回日本臨床血液学会総会（昭和58年 10月29日)において発表した。
して多薬併用療法中に組又込亦机広く用いられて いる。その主たる副作用は神経障害で，深部反射 の消失や知覚異常などの末梢神経障害はしばしば

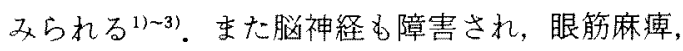
声帯麻㽻なども来すとされるいー4)、しかし，中枢神 経である視神経障害は，非常にまれで，これまで， 欧米では散見されるが5ー10)，本邦では未だ報告を 
みていない，我々は，non-Hodgkinリンパ腫の治 療中，VCRによると思われる視神経障害を来した 1 例を経験したので，若干の文献的考察を加壳， ここに報告する。

\section{症例}

患者：43才，男性。

主訴：発熱。

家族歴特記すべきことなし。

既往歴 2 才の時, 肺炎に罹患. 16才の時, 痔瘦の手術を受ける。

現病歴：昭和 56 年 2 月, 霧視出現. 当院眼科 にてブドゥ膜炎と診断され，ステロイド薬の投与 により軽快した。同年11月ょり，発熱，盜汗，表 在リンパ節腫大をみたため，昭和57年 1 月，当科 入院となる。胸部X線像上異常は認めなかつたが, 肝怙よび䅡部りンパ節生検所見からサルコイドー シスと診断，prednisolone $30 \mathrm{mg} / \mathrm{d}$ を投与され軽 快退院した。しかし，7月より，再び $38 ３ 9^{\circ} \mathrm{C} の$ 発熱, 肝腫大, 表在リンパ節腫大が出現したため, 8 月再入院となる.

入院時現症：体格中等, 意識清明, 体温 $38.1^{\circ} \mathrm{C}$, 血王 $110 / 70 \mathrm{mmHg}$, 脈拍 $90 /$ 分, 整, 費血 (一), 黄疸 (一), 両側顎下，頝部，鎖骨上简，腋 窝，絾径部に小豆大のリンパ節を軟らかく触知，
胸部異常なし，肝 3 横指触知，四肢，皮層拉よび 神経系に異常なし。

入院時検查所見：表 1 少亏に，血沈の軽度 元進がある。生化学検查では，軽度の訮機能障害 を認め，CRP $(4+)$, 細菌学的検查では，一般菌， 結核菌共に陰性であつた，胸部X線像では，綎隔の 抬大および左肺門りンパ節腫脹が認められた，肝 シンチでは，肝腫大㧍よび 2 個のfocal defectを, 腹部CTでは，傍大動脈リンパ節腫大がみられた。 全身のガリウムシンチでは，䅡部，腋窩，肝，左 肺門部に異常集積が認められた。

入院後経過（図 1)：昭和57年 7 月以降pred-

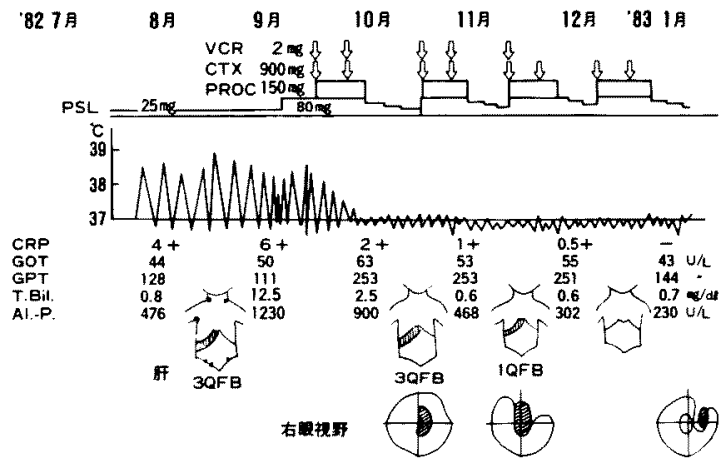

因1。臨床経過

表 1 、入院時検查所見

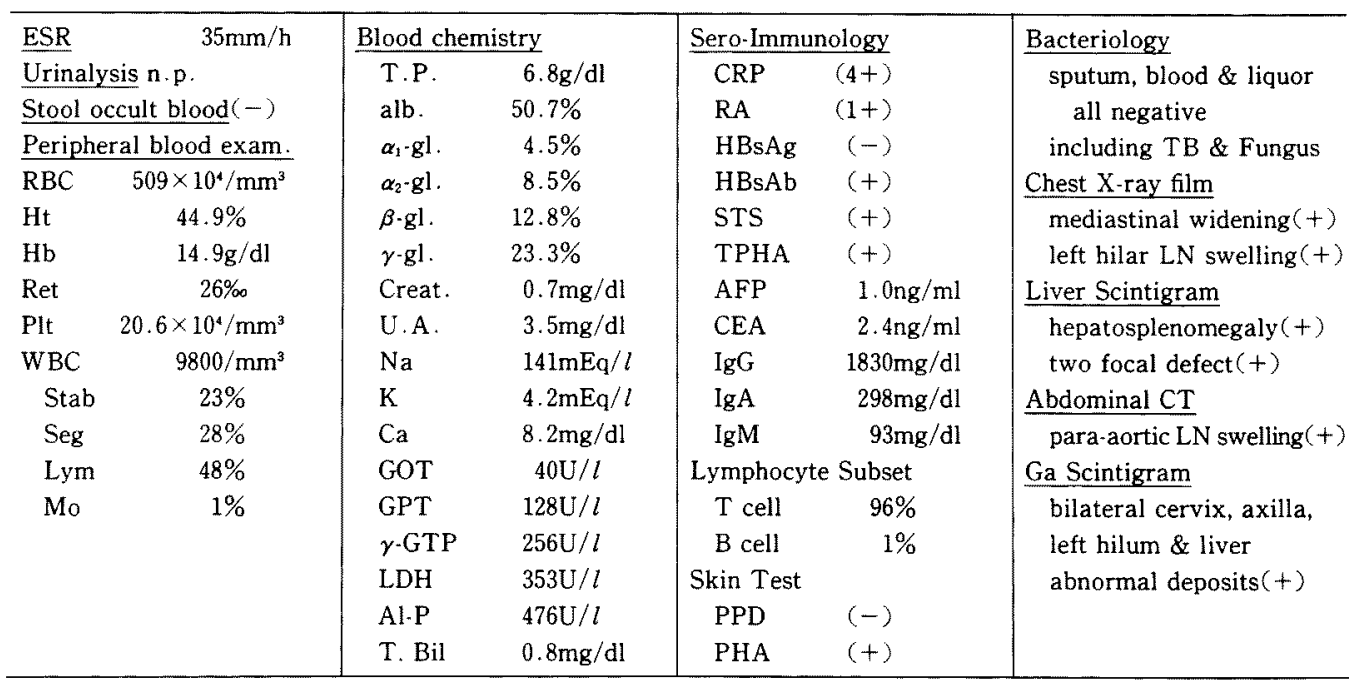


nisolone $25 \mathrm{mg} / \mathrm{d}$ 投与にもかかわらず，発熱は持 続した。 8 月中旬には，左肺門リンパ節打よび肝 腫の増大がみられ, 肝機能障害は進行, 黄疸, 胸 水, 腹水も加わり, 全身状態は急速に悪化した。 再度, 䅡部リンパ節を生検したところ, 類上皮細 胞性肉芽腫の周囲に，核に?びれや，枚じれを有 する異常リンパ球の浸潤がみられた。初回入院時 のリンパ節生検像再検討の結果も同様で, lymphoepitheloid cellular lymphoma, いわゆる Lennert's lymphoma と診断された。9 月20日よ り, cyclophosphamide $900 \mathrm{mg}$ 第 $1 ， 8$ 日目静注, VCR 2mg第 1，8 日目静注, procarbazine 150 $\mathrm{mg} / \mathrm{d}$ 第 1 日目より14日間経口, prednisolone 80 $\mathrm{mg} / \mathrm{d}$ 経口によるCOPP療法を開始したところ, 下 熱し, 腫大リンパ節および胸水, 腹水の消失, 肝 腫の縮小, 肝機能の改善をみた。ところが 2 クー ル目施行中 (VCR計 $6 \mathrm{mg}$ 投与) 上り, 視野縮小等 の視力障害が出現し, ほぼ同時に, 指尖のしびれ, 遠位筋に優位の筋力低下拉上び深部反射の減弱が 出現した。眼科的検索では, 両側, 特に右眼のマ リオット盲点の拡大と後天性色覚異常が認められ たが，眼圧および眼底は正常で，脳脊髄液所見お よび頭部CTでは異常を認めなかつた.これらの所 見から，VCRの副作用としての視神経障害を疑 い, COPP療法 3 クール目後半上り同薬物を中止 したところ, 徐々に眼症状拈よび暗点の改善がみ られた。図 2 は, 上方が眼症状増悪時の右眼視野 で，下方がVCR投与中止 3 力月後のものである. 拡大していた暗点の縮小が認められる。悪性リン 働の完全寛解を得たため, 昭和58年 3 月退院し 外来で経過観察中であるが, 現在, 眼症状は全く 消失している。

\section{考案}

本例にみられた暗点の拡大と色覚異常は, 眼底 扣よび眼圧が正常なことから，らつ血乳頭や緑内 症ではなく，球後視神経障害と考えられる。視神 経障害は，希れではあるが，悪性リンパ腫の浸潤 の際にもみられる1112) しかし，本例では，脳资䯣 液検査や, 頭部CT所見に異常がみられなかつたこ と, 治療により, 悪性リンパ腫による諸症状の改

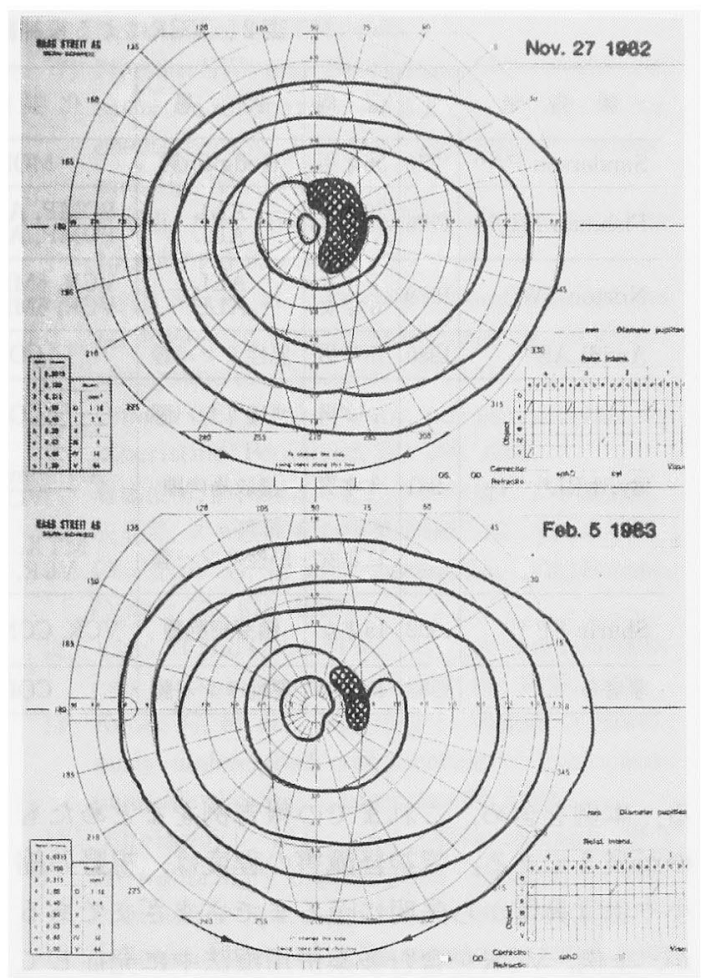

因2. 右眼視野

3 カ月後の視野 (下方) では, 拡大していた暗点の 縮小が認められる。

善がみられたにもかかわらず，むしろ，眼症状は 増悪していることなどから，悪性リンバ腫が原因 であるとは考劣にくい，一方, 眼症状の出現時期 にほぼ一致して，VCRによると思われる末梢神経 障害が出現していること, また, VCRの投与中止 により，眼症状の改善をみていることなどから， VCRによる視神経障害が, 最も考光易い。本例で はCOPP療法として, VCR以外の薬物も同時に使 用しているが, これまでcyclophosphamideや procarbazineによる視神経障害の報告はない13) 前者による視力障害の報告はみられるが，一過性 であり，傷害部位も不明である ${ }^{14)}$. 本例でみられた 視神経障害は, やはり, 基本的に神経毒性物質々 されるVCRによるものと考兄らる。

VCRによる視神経障害は，これまで欧米で 7 例，皮質盲を含めると10例の報告がみられるが， 本邦では末だ報告なく，極めて希れなものと考光 
表 2、VCRによる視神経障害（皮質富を含む）の報告

\begin{tabular}{|c|c|c|c|c|c|c|c|c|}
\hline 報 告 者 & 年 & 症 例 & 疾 & 化学療法 & 故射線照射 & $\begin{array}{c}\text { 視力障害出現 } \\
\text { までVCR総量 } \\
\end{array}$ & $\begin{array}{l}\text { VCRによる他 } \\
\text { の副作用 }\end{array}$ & 転㷌 \\
\hline Sanderson $\mathrm{PA}^{\mathrm{s}}$ & 1976 & 36才男 & Hodgkin病 & MOPP & - & $48 \mathrm{mg}$ & 末梢神経障害 & 失明 \\
\hline Fishman $\mathrm{ML}^{6)}$ & 1976 & $\begin{array}{l}20 才 女 \\
2.5 才 女\end{array}$ & $\begin{array}{l}\text { ALL } \\
\text { ALL }\end{array}$ & $\begin{array}{l}\text { POMP, AraC鲢注 } \\
\text { POMP, AraC髄注 }\end{array}$ & $\begin{array}{l}+ \\
+ \\
+\end{array}$ & $\begin{array}{l}18 \mathrm{mg} / \mathrm{m}^{2} \\
22 \mathrm{mg} / \mathrm{m}^{2}\end{array}$ & $\begin{array}{l}\text { 記戴なし } \\
\text { 記载なし }\end{array}$ & 失盟 \\
\hline Norton SW ${ }^{7}$ & 1979 & $\begin{array}{l}7 才 女 \\
6 \text { 才女 }\end{array}$ & $\begin{array}{l}\text { ALL } \\
\text { ALL }\end{array}$ & $\begin{array}{l}\text { VCR, 6MP, MTX } \\
\text { VCR, 6MP, MTX }\end{array}$ & $\overline{-}$ & $?$ & $\begin{array}{l}\text { 記載なし } \\
\text { 記載なし }\end{array}$ & $\begin{array}{l}\text { 回復 } \\
\text { 回復 }\end{array}$ \\
\hline A widi $A S^{B i}$ & 1980 & 18才男 & 悪性リソパ畽 & $\mathrm{COP}$ & - & $10 \mathrm{mg}$ & な & 失明 \\
\hline \multirow{3}{*}{ Byrd RL" } & \multirow{3}{*}{1981} & 7 戈男 & 悪性リンパ腫 & $\mathrm{COP}$ & - & $2 \mathrm{mg} / \mathrm{m}^{2}$ & 㿋䈃反イ射低下 & 回復 \\
\hline & & 3才男 & 满紋筋肉嗹 & $\begin{array}{c}\text { Actinomycin } D \\
\text { VCR }\end{array}$ & - & $5.4 \mathrm{mg} / \mathrm{m}^{2}$ & $\begin{array}{l}\text { 発熱, イレウス } \\
\text { SIADH } \\
\text { 茉梢神経障害 }\end{array}$ & 回復 \\
\hline & & & 覀性リンバ腫 & $\begin{array}{l}\text { MTX, Lasp, } \\
\text { VCR, PSL }\end{array}$ & - & $3 \mathrm{mg} / \mathrm{m}^{2}$ & 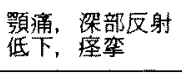 & 回徂 \\
\hline Shurin $\mathrm{SB}^{109}$ & 1982 & 15才女 & 髉芽細胞腫 & VCR, CCNU, PSL & + & $18 \mathrm{mg}$ & $\begin{array}{l}\text { 登熱, 未梢神経 } \\
\text { 音意識限害 }\end{array}$ & 回復 \\
\hline 著者ら & 1983 & 43才男 & 覀性リンバ㮔 & COPP & - & $6 \mathrm{mg}$ & 末梢神経障害 & 回復 \\
\hline
\end{tabular}

る、本例を含め、これまでの報告例をむとめだす

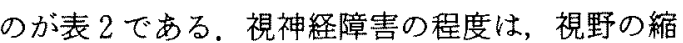
小や色覚異常から失明に至るまでさまざるである が，全例，VCRを含む多薬併用療法中に発症して いる．頭部放射線照射を受けたるのが 3 例みられ る。視神経障害出現までのVCR棇投与量は, $2 \mathrm{mg} /$ $\mathrm{m}^{2}$ の少量から約 $50 \mathrm{mg}$ まで，広範囲にわたつてい るが，少量で発症しているものが比較的多い，約 半数の例で, 視神経障害出現時, VCRによる他の 何らかの副作用がみられているが，初発症状とし て出現しているものもある8) 視神経障害の予後 として，VCRの投与を中止した 8 例中 7 例で回復 がみられている一方，失明に至つたものが 4 例あ り，このらち3例では，基礎疾患による病変が疑 われ，放射線療法やVCRを含む化学橑法がさらに 追加されている。

病理学的に楉萦されたSanderson $5^{57}$, Fishman $5^{6)}$ の例では，黄斑部の神経節細胞の消失や，視神 経の脱髄化，軸索変性などがみられているが，こ れらの所見は，VCRによる末梢神経障害時にみら れるものと同様である。この機序としてShelanski $ら^{15)}$ はmicrotubulesの破壊と neurofilamentsの増 生がaxoplasmic flowk障害を与え, 軸索膜の機能 障害を来すためであるらと推定している。
一般に, VCRの神経障害はdose-dependentとさ れるが(1 3)，少量で出現をみたという報告もあ $\eta^{16) 171}$ ，これらでは，VCRに対する個体の感受性 が高いためによると考劣られている。視神経障害 は比較的少量のVCR投与で出現しており，その発 症には，やはり，個体の感受性が強く影響するも のと思われる。また放射線照射は，照射線量が多 ければ，それのみで，網膜や視神経の萎縮を引き 起こすとされる ${ }^{18)}$ ．しかし，照射線量が少なくて も，血管の内皮細胞を傷害するため，VCRの blood-brain barrierの通過を容易にさせると考文 られる ${ }^{19)}$ したがつて，頭部の放射線療法を併用す る場合は，その効果が期待できる反面，VCRの毒 性も強く出現寸る可能性があり注意が必要と思わ れる. 本例はVCR投与時，悪性リンパ腫の肝内漫 潤により著明な肝内胆汁うつ滞性黄疸を呈してい た、VCRは肝缄で代謝され，胆计中に排泄される ため"，本例では，VCRが血中に長時間，高濃度に 残存し，少量のVCRで視神経障害を含む種々の副 作用出現に至つたものと考觉る。

視神経障害の予後は良好で，これまでの報告を みても，早期にVCRの投与を中止したものでは， ほとんどの例で視力の回復が得られている。この ことは他のVCRの神経障害と同様, 視神経障害は 
基本的には可逆性と考えられる，悪性腫湟の治療 中に視神経障害が出現した時, 臨床経過や諸検查 などから，瘇場による視神経障害が否定的である 場合には，希れではあるが，VCRによる視神経障 害を考慮することが必要と思われる。

\section{結語}

VCRによると思われる視神経障害を来した non-Hodgkinリンパ腫の 1 例を報告した。こ机ま での欧米の報告例では失明に至つた例がある一 方，早期に投与中止されたものでは，本例と同様， ほとんどの例が回復している。したがつて，悪性 腫瘍の治療中，視神経障害をみた場合，希れでは あるが，VCRによる視神経障害も念頭に扣く必要 がある。本例のごとき肝機能障害時のVCR投与 は，副作用が特に出現し易く，十分注意すべきと 思われる。

謝辞 最後に，本学眼科，西山文子先生の御教示に感謝 致します。

\section{文献}

1) Sandler SG, et al: Vincristine-induced neuropathy. Neurology 19:367, 1969.

2) Rosenthal $S$ and Kaufman $S$ : Vincristine neurotoxicity. Ann Intern Med 80: 733, 1974.

3) Weiss HD, et al: Neurotoxicity of commonly used anti-neoplastic agents. Second of two parts. New Engl J Med 291: 127, 1974.

4) Albert DM, et al: Ocular complications of vincristine therapy. Arch Ophthal 78: 709, 1967.

5) Sanderson PA, et al: Optic neuropathy presumably caused by vincristine therapy. Amer J Ophthalmol 81 : 146, 1976.

6) Fishman ML, et al : Optic atrophy following prophylactic chemotherapy and cranial radiation for acute lymphocytic leukemia. Amer J
Ophthalmol 82:571, 1976.

7) Norton SW and Stockman JA: Unilateral optic neuropathy following vincristine chemotherapy. J Pediatr Ophthalmol Strabismus $16: 190,1979$.

8) Awidi AS: Blindness and vincristine. Ann Intern Med 93: 781, 1980.

9) Byrd RL, et al: Transient cortical blindness secondary to vincristine therapy in childhood malignancies. Cancer 47:37, 1981.

10) Shurin SB, et al: Optic atrophy induced by vincristine. Pediatrics $70: 288,1982$.

11) 高橋俊博, 諫山義正: 恶性リン八腫に上る視神経, 視交丒、クモ膜障害の病理。眼紀 $31 ： 1118,1980 。$

12) Qualman SJ, et al: Intraocular lymphomas. Cancer $52: 878,1983$.

13) Vizel M and Oster MW: Ocular side effects of cancer chemotherapy. Cancer $49:$ 1999, 1982.

14) Kende $G$, et al : Blurring of vision. A previously undescribed complication of cyclophosphamide therapy. Cancer 44:69, 1979.

15) Shelanski $M L$ and Wisniewski $H$ : Neurofibrillary degeneration: Induced by vincristine therapy. Arch Neurol $20: 199,1969$.

16) Johnson FL, et al: Seizures associated with vincristine sulfate therapy. J Pediatr 82:699, 1973.

17) O'Callaghan $\mathrm{MJ}$ and Ekert $\mathrm{H}$ : Vincristine toxicity unrelated to dose. Arch Dis Child 51 : 289, 1976.

18) Shukovsky LJ and Fletcher GH : Retinal and optic nerve complications in a high dose irradiation technique of ethmoid sinus and nasal cavity. Radiology $104: 629,1972$.

19) Schettler $T$ and Shealy $C N$ : Experimental selective alteration of blood-brain barrier by X-irradiation. J Neurosurg 32: 89, 1970. 